\title{
Genetic Factors in Diabetes Mellitus Studied by the Oral Glucose Tolerance Test
}

\author{
G. S. THOMPSON \\ From the Nuffield Unit of Medical Genetics, Department of Medicine, University of Liverpool
}

The hereditary basis of diabetes has been suspected for over 2000 years. It is, however, only in the past 30 years that an inherited factor has been conclusively demonstrated by means of family studies (Pincus and White, 1933, 1934; Steinberg and Wilder, 1952; Simpson, 1962, 1964). In the numerous investigations of the genetics of this disorder different approaches have been made and several modes of inheritance have been advanced to explain the observed facts. The most widely held view for a number of years has been that of a single-gene recessive mechanism (Steinberg, 1959). A variant of this theory was suggested by Harris (1949, 1950), who presented evidence that earlyonset diabetes was due to the homozygous state, whereas late-onset diabetes was due to the heterozygous state. The principal alternative view, suggested by the findings of Keen (1957) (quoted by Pyke, 1959), and more recently by Simpson (1964), is of polygenic inheritance, i.e. the disease is thought to be controlled by many genes each with a small additive effect. These conclusions have been reached by studying oral glucose tolerance and the incidence of overt diabetes in relatives of diabetic propositi. In recent years, using a different method altogether, support for a dominant pattern of inheritance in essential diabetes has been presented by Vallance-Owen (1964) from studies of plasma-insulin antagonist activity in diabetic families. The present investigation was designed to try and clarify the problem and, in particular, to test the single-gene versus the multifactorial hypothesis.

\section{Present Investigation}

An oral glucose tolerance test was performed on healthy first-degree relatives of patients with diabetes, since it is now generally agreed that the unstressed oral glucose tolerance test is the best

Received July 8, 1965. diagnostic test in diabetes mellitus (see Taton, Pometta, Camerini-Dávalos, and Marble, 1964). If the blood sugar level is a good index of the primary defect in diabetes, then on the single-gene hypothesis one would expect bimodality in the distribution of blood sugar values in the relatives. If differences in environment could be eliminated entirely bimodality would be bound to appear on the single-gene view. On the other hand a continuous distribution from normal to abnormal values would suggest multifactorial control of blood sugar concentration (Clarke, I96r). The results have been further analysed to assess the effect of age, body-build, and sex on the blood sugar concentration in case-relatives and controls.

\section{Subjects and Methods}

Clinical Material. Oral glucose tolerance tests were performed on $27 \mathrm{I}$ subjects, who were divided into 2 groups.

(I) The positive family history group: 164 persons with at least one living first-degree diabetic relative.

(2) The control group: I07 persons with no known diabetic relatives.

The two groups of subjects were derived from the same area and it is assumed that environmental effect(s) would be fairly similar for these two population groups. The distribution of age and sex of these individuals is shown in Table I.

TABLE I

AGE AND SEX DISTRIBUTION OF INDIVIDUALS STUDIED

\begin{tabular}{c|c|c|c}
\hline Age-group & Sex & Controls & Relatives \\
\hline I6-30 & M & 13 & 12 \\
$31-45$ & M & 11 & 16 \\
$46-60$ & F & 9 & 27 \\
M & F & 24 & 35 \\
& M & 21 & 37 \\
& F & 7 & 35 \\
\hline Total & M & 53 & 9 \\
\hline & F & 54 & 69 \\
\hline
\end{tabular}


TABLE II

MEAN AGE, WITH STANDARD ERROR, OF GROUPS STUDIED

\begin{tabular}{|c|c|c|c|c|}
\hline & \multicolumn{2}{|c|}{ Controls } & \multicolumn{2}{|c|}{ Relatives } \\
\hline & Male & Female & Male & Female \\
\hline $\begin{array}{l}\text { Mean age (yr.) } \\
\text { Standard error } \\
\text { of mean }\end{array}$ & $\begin{array}{r}45 \cdot 60 \\
\pm I \cdot I 4\end{array}$ & $\begin{array}{r}44 \cdot 4 I \\
\pm I \cdot I 7\end{array}$ & $\begin{array}{r}42 \cdot 7 I \\
\pm I \cdot 29\end{array}$ & $\begin{array}{r}44 \cdot 05 \\
\pm I \cdot 30\end{array}$ \\
\hline
\end{tabular}

The mean age and standard error for each sex in the two groups studied are shown in Table II.

Glucose Tolerance Test. The conditions before and during the performance of the oral glucose tolerance test were standardized. Subjects were requested to take a normal unrestricted diet for 3 days before the test. In addition to overnight fasting they were asked not to smoke on the morning of the investigation. When a fasting venous blood sample had been taken, a calculated dose of glucose was drunk over a period of 5 minutes. The ordinary clinical test does not take into account variation in the body mass, therefore $0.7 \mathrm{~g}$. glucose/kg. metabolically active mass (MAM $=$ Wt. ${ }^{\cdot \cdot 7}$ ) was consumed (Drabkin, I959) (Table III). Venous blood samples were withdrawn at 30-minute intervals for two and a half hours. The blood sugar was estimated using a Technicon 'AutoAnalyzer' (Technicon AutoAnalyzer Methodology, I960).

TABLE III

DOSAGE SCHEDULE: 0.7 g. glucose/kg. MAM

\begin{tabular}{|c|c|c|c|}
\hline $\begin{array}{l}\text { Wt. } \\
\text { (kg.) }\end{array}$ & $\begin{array}{l}\text { Vol. Glucose Soln } \\
\text { (ml.) (50 g./100 ml.) }\end{array}$ & $\underset{(\mathrm{kg} .)}{\mathbf{W t}}$ & $\begin{array}{l}\text { Vol. Glucose Soln } \\
\text { (ml.) (50 g./100 ml.) }\end{array}$ \\
\hline $\begin{array}{l}30 \\
35 \\
40 \\
45 \\
50 \\
55 \\
60 \\
65\end{array}$ & $\begin{array}{l}54 \\
60 \\
66 \\
72 \\
77 \\
83 \\
88 \\
93\end{array}$ & $\begin{array}{r}70 \\
75 \\
80 \\
85 \\
90 \\
95 \\
100 \\
105\end{array}$ & $\begin{array}{r}98 \\
103 \\
107 \\
112 \\
117 \\
121 \\
126 \\
130\end{array}$ \\
\hline
\end{tabular}

As the glucose tolerance test involves a series of blood sugar concentrations, it was necessary to express the result of each test as a single value, rather than by scoring each curve as 'normal' or 'abnormal' on the basis of arbitrarily defined blood sugar levels. After considering various expressions the mean of the half-, one-, and one and a half-hour blood sugar values after ingestion of glucose was preferred, and this is described by the term 'mean blood sugar'. This value was chosen since it is now recognized that, in addition to the peak blood sugar level, a delayed fall of blood sugar towards fasting levels occurs as an early sign of impaired carbohydrate tolerance. Furthermore, the use of this mean value also minimizes the effect of variable gastrointestinal absorption of glucose.

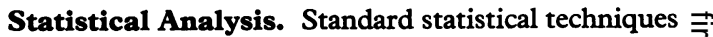
were used throughout (Bailey, 1959). It was found that $\stackrel{5}{+}$ the distribution of the mean blood sugar concentrations $\bar{C}$ expressed as $\mathrm{mg}$./100 $\mathrm{ml}$. was positively skewed. $\log _{10} \frac{\bar{\sigma}}{\sigma}$ transformations gave approximately normal distributions, $\overline{\bar{D}}$ and therefore these transformations were used in $\Phi$ computations.

Body build was calculated by dividing the body $\infty$ weight (lb.) by height (in.). Age and body build were $\overrightarrow{0}$ normally distributed, and therefore comparison of groups by partial regressions was employed (Bailey, $\vec{\omega}$ I959). Thus it is possible to study a pair of independent variables, i.e. age and body build, upon the mean blood sugar.

The technique of Scheffé (1953) was used to compare N the blood sugar values for male and female subjects in the controls and case-relatives. This method circum- N vents the difficulties of multiple t-testing. The confidence limits of a difference as determined by this method are detailed in Appendix I.

Analysis of reproducibility of the oral glucose tolerance test in this investigation is shown in Appendix II.

\section{Results}

It is evident from the histograms (Fig. I and 2) $\overrightarrow{0}$ that there is a continuous distribution of age-cok $\&$ rected (see below) blood sugar values in each of the groups, namely controls and case-relatives of bot sexes, with no clear-cut division into normal an abnormal values. Thus there was no evidence of a single gene effect, and it is considered that these findings are consistent with a multifactorial mechanism of blood sugar control, though from the data available it was not possible to study parent/child and $\mathrm{sib} / \mathrm{sib}$ correlations.

Influence of Age, Sex, and Body Build upon Blood Sugar Level. There is clearly a relationship between age and blood sugar concentration (Table IV). This was evident in the controls and case-relatives of both sexes. The influence of body build on blood sugar concentration was less marked

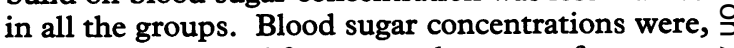
therefore, corrected for age; to the mean of 45 years, $\rightarrow$ and these $\log _{10}$ age-corrected values were used for all computations.

Analysis of Blood Sugar Levels. A detailed $N$ analysis of the four groups of subjects, namely $\omega$ male controls, female controls, male relatives, and female relatives was next considered. It was 6 statistically permissible to use the Scheffé analysis $\mathbb{\Phi}$ (Appendix I). The results are shown in Table V. $\stackrel{?}{?}$ When there is a difference at the level of signifi- $\frac{0}{0}$ 


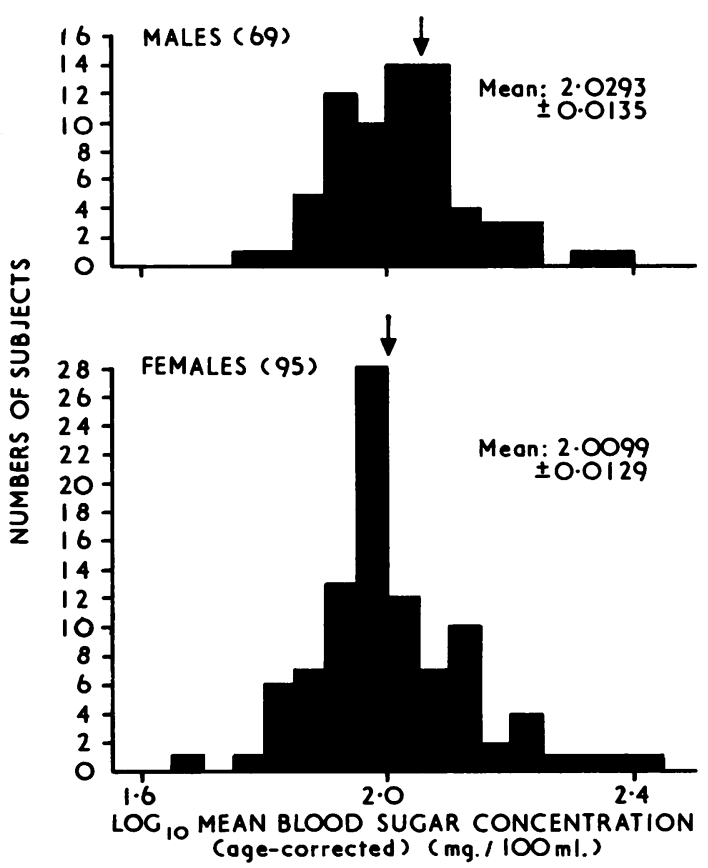

Fig. I. Distribution of $\log _{10}$ mean blood sugar concentration (mg./100 ml.) (age-corrected) in case-relatives.

cance indicated the confidence limits do not overlap zero.

The results in Table $\mathrm{V}$ and Fig. I and 2 show that, in the controls, male subjects had higher age-corrected mean blood sugar values than female ( $p$ $<0.00 \mathrm{r})$. Female relatives had considerably higher age-corrected blood sugar values than female controls $(p \pm p \cdot \infty r)$. In the case-relatives there was no significant difference between male and female subjects. This is because there is a greater rise in the mean blood sugar concentration in female

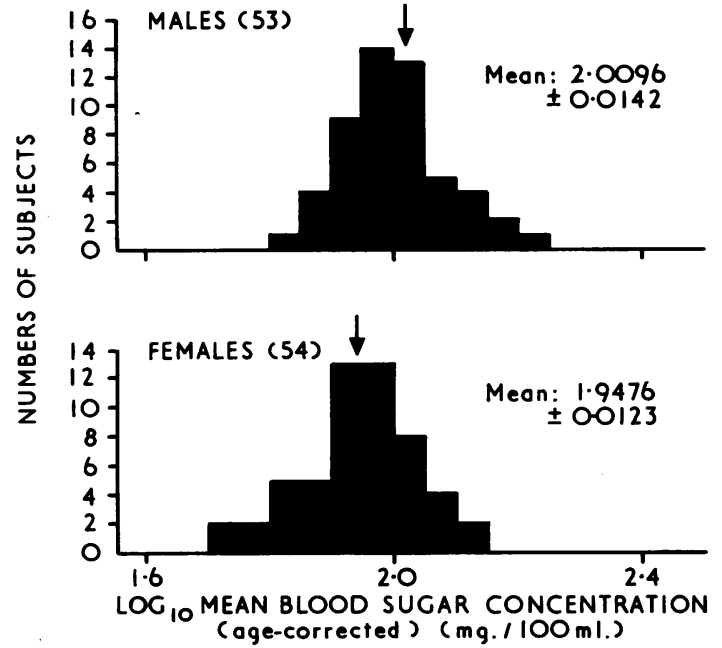

FIG. 2. Distribution of $\log _{10}$ mean blood sugar concentration (mg./100 ml.) (age-corrected) in control subjects.

\section{TABLE V}

COMPARISON OF MEANS OF LOG 10 MEAN BLOOD SUGAR CONCENTRATION (mg./100 ml.)(AGE-CORRECTED IN DIFFERENT GROUPS)

\begin{tabular}{c|c|c|c}
\hline $\begin{array}{c}\text { Groups } \\
\text { Compared }\end{array}$ & $\begin{array}{c}\text { Level of } \\
\text { Probability } \\
(\mathbf{p}) \text { Chosen }\end{array}$ & $\begin{array}{c}\text { Differences } \\
\text { Between Means } \\
(\times \text { roo })\end{array}$ & $\begin{array}{c}\text { Lower Confidence } \\
\text { Limits at Stated } \\
\text { Level of p }\end{array}$ \\
\hline $\begin{array}{c}\text { Female controls } \\
\text { and female } \\
\text { relatives }\end{array}$ & 0.001 & 6.14 & +2.479 \\
$\begin{array}{c}\text { Male controls } \\
\text { and male } \\
\text { relatives }\end{array}$ & 0.20 & 1.97 & -0.92 \\
$\begin{array}{c}\text { Female controls } \\
\text { and male } \\
\text { controls }\end{array}$ & 0.001 & 6.20 & +2.05 \\
$\begin{array}{c}\text { Male relatives } \\
\text { and female } \\
\text { relatives }\end{array}$ & 0.20 & 2.02 & -0.49 \\
\hline
\end{tabular}

TABLE IV

COMPUTED PARAMETERS OF PARTIAL REGRESSIONS OF LOG ${ }_{10}$ MEAN BLOOD SUGAR CONCENTRATION (mg./IOO ml.) UPON AGE (yr.) AND BODY BUILD (weight/height)

\begin{tabular}{|c|c|c|c|c|}
\hline \multirow{2}{*}{ Parameter } & \multicolumn{2}{|c|}{ Controls } & \multicolumn{2}{|c|}{ Relatives } \\
\hline & Males & Females & Males & Females \\
\hline $\begin{array}{l}\text { No. of individuals } \\
\text { Age }\left(b_{1}\right) \pm S . E . \\
\text { Significance of } b_{1} \\
\text { Body build }\left(b_{2}\right) \pm \text { S.E. } \\
\text { Significance of } b_{2} \\
\text { Intercept (a) }\end{array}$ & $\begin{array}{c}53 \\
0.394 \pm 0.079 \\
p<0.01 \\
0.047 \pm 0.033 \\
p>0.10 \\
172\end{array}$ & $\begin{array}{c}0.346^{54} \pm 0.088 \\
p<0.01 \\
0.099 \pm 0.038 \\
p<0.01 \\
158\end{array}$ & $\begin{array}{c}69 \\
0.212 \pm 0.104 \\
p<0.05 \\
0.140 \pm 0.052 \\
p<0.01 \\
160\end{array}$ & $\begin{array}{c}0.455 \pm 0.106 \\
0.45<0.001 \\
p=0131 \\
0.087 \pm 0.31 \\
p<0.05 \\
161\end{array}$ \\
\hline $\begin{array}{l}\text { Mean of age-corrected } \log _{10} \\
\text { Mean blood sugar value } \pm \text { S.E. }\end{array}$ & $\begin{array}{l}2 \cdot 0096 \\
\pm 0.0142\end{array}$ & $\begin{array}{l}1 \cdot 9476 \\
\pm 0 \cdot 0123\end{array}$ & $\begin{array}{l}2 \cdot 0293 \\
\pm 0.0133\end{array}$ & $\begin{array}{l}2 \cdot 0091 \\
\pm 0.0129\end{array}$ \\
\hline
\end{tabular}


relatives than in male relatives, in contrast to the situation in the males where the male relatives are not different from the male controls. Therefore, it is evident that the effect of a positive family history of diabetes is showing itself, with regard to the blood sugar concentration, most markedly in female relatives of diabetics.

\section{TABLE VI}

COMPARISON OF VARIANCE OF LOG $_{10}$ MEAN BLOOD SUGAR CONCENTRATION

\begin{tabular}{l|c|c|c}
\hline & $\begin{array}{c}\text { Number of } \\
\text { Individuals }\end{array}$ & $\begin{array}{c}\text { Variance } \\
\left(\mathbf{S}^{2}\right)\end{array}$ & $\begin{array}{c}\text { Variance Ratio } \\
\text { Controls/Relatives }\end{array}$ \\
\hline $\begin{array}{l}\text { Female controls } \\
\text { Female relatives }\end{array}$ & 54 & $\begin{aligned} 82 \cdot 11 \\
152 \cdot 80\end{aligned}$ & $\mathbf{1} \cdot 86 \mathrm{p}<0.01$ \\
$\begin{array}{l}\text { Male controls } \\
\text { Male relatives }\end{array}$ & 53 & $\begin{array}{r}69 \cdot 08 \\
122 \cdot 13\end{array}$ & $\mathbf{1} \cdot 77 \mathrm{p}<0.01$ \\
\hline
\end{tabular}

Analysis of Variance. There was an increased variability of the mean blood sugar concentration for each sex in the case-relatives compared with the control subjects (Table VI). Thus a positive family history of diabetes results not only in higher mean blood sugar concentrations, particularly in women, but also in a greater spread in the range of blood sugar values in both sexes.

Relationship of Body Weight to Blood Sugar Level. A significant correlation is evident between body weight and mean blood sugar concentration in male and female relatives and in female controls, but not in the male control group (Table VII).

\section{TABLE VII}

REGRESSION OF LOG $_{10}$ MEAN BLOOD SUGAR CONCENTRATION (mg./100 ml.) UPON WEIGHT (lb.)

\begin{tabular}{l|c|c|c|c}
\hline & \multicolumn{2}{|c|}{ Controls } & \multicolumn{2}{c}{ Relatives } \\
\cline { 2 - 6 } & Male & Female & Male & Female \\
\hline No. of pairs of observations & 53 & 54 & 69 & 95 \\
Regression coefficient (b) & 0.0176 & 0.2200 & 0.1755 & 0.1459 \\
Significance of $b$ & $p>0.5$ & $p<0.01$ & $p<0.05$ & $p<0.01$ \\
\hline
\end{tabular}

This is evidence that the blood sugar level in male subjects with no family history of diabetes is less influenced by body weight than in the other groups of subjects. These results are similar to those obtained from the analysis of body build (see Table IV) in which male controls only did not show a significant correlation of blood sugar level with this measurement. Since body build, height, and weight were not significantly different in either the control subjects or the case-relatives of both sexes, thes observed differences in blood sugar cannot be due.? to differences of height or weight of the different $\vec{F}$ groups.

Influence of ABO Blood Group and Salivary $\frac{\overline{\bar{N}}}{\overline{0}}$ ABH Secretor Status in Diabetes Mellitus. $\frac{\sqrt{\sigma}}{\square}$ McConnell, Pyke, and Roberts (1956) found an excess of blood group A among male diabeticis patients, whereas Andersen and Lauritzen (1960) $\vec{\circ}$ noted that male diabetics with early-onset disease- showed an excess of blood group $O$. In the present $\vec{\omega}$ investigation there was no association of blood? group with a family history of diabetes, nor with the level of blood sugar.

Andersen and Lauritzen suggested that non- $\rightarrow$ secretion of $A B H$ substance in the saliva might $N$ mean an increased susceptibility to diabetes, but ${ }_{\circ}^{-}$ again no differences of $\mathrm{ABH}$ secretor status were found in the controls and case-relatives in the $\overrightarrow{-}$ present investigation.

\section{Discussion}

An immediate problem in discussing the genetics $\vec{\bullet}$ of diabetes is the difficulty in defining the disorder. O In practice the varying clinical manifestations sue gest that the disorder is heterogeneous in nature: The severity of the clinical features, age of onsêt, rate of progression, and sensitivity to insulin vary from patient to patient and from one affected응 relative to another. In addition, appreciable dif- $\propto$ ferences in the incidence and pattern of 'complica- $\overrightarrow{\overrightarrow{0}}$ tions' may precede evidence of altered carbohydrate 3 metabolism. It is highly unlikely, therefore, that any single genetic mechanism is responsible for allo cases of diabetes. Most authorities agree that carbohydrate intolerance is the most importantọ aspect of diabetes, and in practice the oral glucose tolerance test is the principal diagnostic test in this: disorder. However, as judged by this test the dis- $O$ turbance of carbohydrate metabolism does not occur in diabetic families in a manner consistent with any오 Mendelian single-factor inheritance pattern.

The present investigation revealed a continuous distribution of age-corrected blood sugar levels with no clear-cut division into normal and abnormalo values in the control subjects and case-relatives, $N$ and it is considered that these results are consistent ${ }_{\omega}^{N}$ with a polygenic mechanism of blood sugar control. O Simpson (1964) came to the same conclusion frome $_{0}$ a similar study of offspring in which both parents $\frac{\bar{\Phi}}{\Phi}$ were diabetic. However, it is possible to look $\stackrel{\oplus}{+}$ at the matter in another way. Vallance-Owen and 0 
Lilley (r96I) have shown that both obese and insulin-dependent diabetics of any age have an excess of plasma insulin antagonist activity. This activity is inherited as a dominant character (Vallance-Owen, 1964). However, not all genetically constituted subjects necessarily develop overt diabetes. It has been suggested (Brit. med.F., 1965) that insulin antagonist activity, as a single-gene effect, may be one of a complex interaction of factors which influence the blood sugar level, and that in this sense the inheritance of diabetes mellitus may be correctly defined as multifactorial.

Although in this present study there was no support for a single-gene difference using the blood sugar as the index of disease, several points of interest were revealed. The analysis of variance demonstrated that there was more variability of blood sugar level in case-relatives of both sexes compared with control subjects. Since the principal source of this variation was the fact of being or not being related to a diabetic, then, unless there is some environmental factor present in the families of diabetics and absent in other families, it is likely that the greater spread of blood sugar values is an inherited character, though there is no indication of the genetic mechanism involved. This finding is evidence of impairment of normal homeostasis in

TABLE VIII

RESULTS OF GLUCOSE TOLERANCE TESTS IN THREE SISTERS OF A MIDDLE-AGED DIABETIC WOMAN

\begin{tabular}{|c|c|c|c|c|c|c|c|}
\hline \multirow{2}{*}{$\begin{array}{c}\text { Sister } \\
\text { No. }\end{array}$} & \multirow{2}{*}{$\begin{array}{l}\text { Age } \\
\text { (yr.) }\end{array}$} & \multirow[t]{2}{*}{ Fasting } & \multicolumn{5}{|c|}{ Blood Sugar (mg./100 ml.) } \\
\hline & & & $\frac{1}{2}-h r$. & I-hr. & I $\frac{1}{2}-\mathbf{h r}$ & 2-hr. & $2 \frac{1}{2}-h r$. \\
\hline $\begin{array}{l}1 \\
2 \\
3\end{array}$ & $\begin{array}{l}51 \\
53 \\
42\end{array}$ & $\begin{array}{l}65 \\
74 \\
67\end{array}$ & $\begin{array}{r}114 \\
87 \\
122\end{array}$ & $\begin{array}{r}109 \\
96 \\
131\end{array}$ & $\begin{array}{c}71 \\
67 \\
53\end{array}$ & $\begin{array}{l}35 \\
39 \\
34\end{array}$ & $\begin{array}{l}56 \\
62 \\
55\end{array}$ \\
\hline
\end{tabular}

This tendency to hypoglycaemia at 2 hours is clearly not due to a 'lag' curve.

the relatives of diabetics and suggests that before the development of overt diabetes the blood sugar level is more labile than normal. In this context it is of interest that in children and adults, symptoms of hypogfycaemia may precede those of diabetes (Seltzer, Fajans, and Conn, 1956). To illustrate this tendency to hypoglycaemia, the glucose tolerance tests of three sisters of a middle-aged diabetic woman in the present series are presented (Table VIII).

In recent years attention has again been attracted to the association between obesity and diabetes (Joslin, Root, White, and Marble, 1959; Lancet, 1965), and the findings in the present investigations have demonstrated differences due to body weight, sex, and family history in four groups tested (caserelatives and control subjects of both sexes). The raised blood sugar levels in female case-relatives and the positive correlation between body weight and blood sugar in all groups except male control subjects are evidence that obesity leads to increased blood sugar concentrations in case-relatives of both sexes and in women, whether or not there is a family history of diabetes, but not in men without a family history. The findings in women might account for the high incidence of diabetes in obese middleaged women. Medley (1965) has also reported an association between obesity and impaired glucose tolerance, particularly in subjects with a positive family history. In his investigation obesity without a positive family history showed a much smaller effect. However, Medley did not analyse the results for each sex separately. Furthermore, it is also of interest that the findings in the present investigation offer no support to the hypothesis that a diabetic gene exists, which is responsible for the tendency to gain weight in this disease in female patients. Nilsson (1962) reported that at the ages of 18 years and about 50 years, the relatives of diabetics tended to be taller and heavier than controls; the differences, however, were not significant. Thus the hypothesis that the tendency to increased growth in diabetes may be hereditary (Garn, Clark, Landkof, and Newell, 1960) remains unproven, though it seems likely that obesity may favour the penetrance of a diabetic gene(s) as far as the disturbance of carbohydrate metabolism is concerned.

\section{Summary}

An experiment based on the results of glucose tolerance curves was designed to test the hypothesis that the genetic control of diabetes depends upon a single gene. If the blood sugar is a good index of the disorder then on this hypothesis a bimodal distribution of blood sugar values would be expected. If environmental variability could be eliminated entirely, bimodality would be bound to appear on the single-gene view. Glucose tolerance tests performed on 164 case-relatives and 107 control subjects showed a continuous distribution of blood sugar concentrations with no clear-cut division into normal and abnormal values in either series. This does not support the single gene theory and suggests a multifactorial mechanism of blood sugar control.

A genetic influence was demonstrated since: (a) case-relatives had more labile blood sugar values than controls, thus suggesting that there is im- 
pairment of normal homeostasis with regard to the blood sugar level in male and female subjects with a family history of diabetes; and (b) female caserelatives had higher mean blood sugar values than controls. The results relating to body weight show that obesity leads to higher blood sugar values in (a) both male and female subjects with a positive family history and (b) the female sex generally. These findings accord with clinical experience, namely the high incidence of diabetes in obese women whether or not there is a positive family history of diabetes.

I gratefully acknowledge the continued advice of Dr. C. A. Clarke who suggested this investigation. I also wish to thank Dr. D. A. Price Evans for his generous kelp with the statistical analysis. This study was supported by a research grant from the British Diabetic Association.

\section{REFERENCES}

Andersen, J., and Lauritzen, E. (1960). Blood groups and diabetes mellitus. Diabetes, $9,20$.

Bailey, N. T. J. (1959). Statistical Methods in Biology. English Universities Press, London.

Brit. med. F. (1965). Inheritance of diabetes mellitus. I, 940.

Clarke, C. A. (1961). The genetics of diabetes mellitus. Diabetes, I0, 175 .

Drabkin, D. L. (1959). Imperfection: Biochemical phobias and metabolic ambivalence. Perspect. Biol. Med., 2, 473.

Garn, S. M., Clark, A., Landkof, L., and Newell, L. (1960). Parental body build and developmental progress in the offspring. Science, 132, 1555 .

Harris, H. (1949). Incidence of parental consanguinity in diabetes mellitus. Ann. Eugen. (Lond.), 14, 293.
(1950). The familial distribution of diabetes mellitus: a study of the relatives of $124 \mathrm{I}$ diabetic propositi. ibid., 15, 95.

Joslin, E. P., Root, H. F., White, P., and Marble, A. (1959). The Treatment of Diabetes Mellitus, Ioth ed., Kimpton, London.

Keen, H. (I957). Paper read to Banting Memorial Meeting of the British Diabetic Association, Oxford. (Abstr. Lancet, 1957, 2, 124.)

Lancet (1965). Obesity and diabetes. I, 1260.

McConnell, R. B., Pyke, D. A., and Roberts, J. A. F. (1956), Blood groups in diabetes mellitus. Brit. med. F., 1, 772.

Medley, D. R. K. (1965). The relationship between diabetes and obesity: a study of susceptibility to diabetes in obese people. Quart. F. Med., 34, III.

Nilsson, S. E. (1962). Genetic and constitutional aspects of diabetes mellitus. Acta med. scand., 171, Suppl. 375.

Pincus, G., and White, P. (1933). On the inheritance of diabetes mellitus. I. An analysis of 675 family histories. Amer. F. med. Sci., 186, I.

- and - (1934). On the inheritance of diabetes mellitus. III. The blood sugar values of the relatives of diabetics. ibid., 188, 782.

Pyke, D. A. (1959). Aetiological factors in diabetes. Postgrad. med. F., 35, 261.

Scheffé, H. (1953). A method for judging all contrasts in the analysis of variance. Biometrika, 40,87.

Seltzer, H. S., Fajans, S. S., and Conn, J. W. (1956). Spontaneous hypoglycemia as an early manifestation of diabetes mellitus. Diabetes, 5, 437.

Simpson, N. E. (1962). The genetics of diabetes: a study of 233 families of juvenile diabetics. Ann. hum. Genet., 26, I.

- (1964). Multifactorial inheritance: a possible hypothesis for diabetes. Diabetes, 13, 462.

Steinberg, A. G. (I959). The genetics of diabetes: a review. Ann. N.Y. Acad. Sci., 82, 197.

- and Wilder, R.M. (1952). A study of the genetics of diabetes mellitus. Amer. F. hum. Genet., $4,113$.

Taton, J., Pometta, D., Camerini-Dávalos, R. A., and Marble, A. (I964). Genetic determinism to diabetes and tolerance to glucose. Lancet, 2,1360 .

Technicon AutoAnalyzer Methodology (1960). Method File Reis 2-I I-60.

Vallance-Owen, J. (1964). Insulin antagonists and inhibitors. Advanc. Metabol. Disorders, 1, 191.

and Lilley, M. D. (196I). Insulin antagonism in the plasma of obese diabetics and prediabetics. Lancet, 1, 806 .

\section{APPENDICES}

\section{Appendix I}

The analysis of variance of age-corrected mean blood sugar concentrations in the four group categories studied showed a significantly greater variation between the categories than within them $(p<0.001)$; therefore, the Scheffé (1953) analysis was computed. The confidence limits of a difference as determined by this method are:

$$
\pm \sqrt{(k-\mathrm{I}) F_{\alpha(k-1) n_{2}} \times \frac{M S_{w g}}{N_{1}}+\frac{M S_{w g}}{N_{2}}}
$$

where: $k=$ number of group categories; $\mathrm{F}$ is obtained from variance ratio tables at a probability; $n_{2}=$ degrees of freedom within these categories; $M S_{w g}=$ mean square within these categories; $N_{1}$ and $N_{2}=$ number of observations in the categories compared.

\section{Appendix II}

Reproducibility of Oral Glucose Tolerance Test

A series of 40 oral glucose tolerance tests was carried out on 20 healthy medical student volunteers with an interval of one to three weeks between the duplicate tests. There was a high correlation coefficient, $\mathbf{r}=$ 0.89 , of duplicate tests, which is highly significant ( $p<0.001)$. This is evidence of satisfactory reproducibility of the oral glucose tolerance test as performed in this investigation when the mean blood sugar concentration of half-, one-, and one and a half-hour values is used to express the result. 